\title{
Vibrio vulnificus tonsillitis after swimming in the Gulf of Mexico
}

\author{
Ali A Alsaad, ${ }^{1}$ David Sotello, ${ }^{2}$ Brian T Kruse, ${ }^{3}$ Jennifer B Cowart ${ }^{1}$
}

${ }^{1}$ Internal Medicine, Mayo Clinic Florida, Jacksonville, Florida, USA

${ }^{2}$ Infectious Disease, Mayo Clinic Florida, Jacksonville, Florida, USA

${ }^{3}$ Emergency Medicine, Mayo Clinic Florida, Jacksonville, Florida, USA

\section{Correspondence to}

Dr Ali A Alsaad, alsaad.ali@ mayo.edu

Accepted 7 June 2017
CrossMark

To cite: Alsaad AA, Sotello $D_{\text {, }}$ Kruse BT, et al. BMJ Case Rep Published Online First: [please include Day Month Year]. doi:10.1136/bcr-2017221161

\section{DESCRIPTION}

A 55-year-old man with decompensated cirrhosis secondary to Laennec's (alcoholic) cirrhosis and insulin-dependent diabetes mellitus presented with acute dysphagia and left-sided neck pain within hours of swimming in the Florida Gulf of Mexico. He did not ingest raw seafood, eat raw vegetables washed with fresh water or intentionally drink sea water prior to the presentation. He reported no gastrointestinal complaints. On examination, temperature was $39.1^{\circ} \mathrm{C}$, and heart rate was 109 beats per minute with normal blood pressure. $\mathrm{He}$ appeared generally toxic and had an inflamed, ulcerated left tonsil; later, an axillary skin lesion developed with no trauma to the axillary area (figure 1). Neck CT showed submucosal tonsillar oedema, enlarged left palatine tonsil and reactive lymphadenopathy, consistent with acute tonsillitis (figure 2).

Treatment was initiated with ampicillin/ sulbactam and then changed to piperacillin/tazobactam when blood cultures grew Gram-negative bacilli after 8 hours of incubation. The pathogen was subsequently identified as V. vulnificus with no antimicrobial resistance. Throat culture was negative for Vibrio spp; however, it was positive for herpes virus type-1 (HSV-1). He was treated with oral cefpodoxime, doxycycline and valacyclovir for 14 days, with rapid resolution of symptoms.

V. vulnificus causes severe illness including necrotising soft tissue infection, septicaemia and gastroenteritis, with high mortality. Risk factors include immunocompromised state, diabetes and cirrhosis.

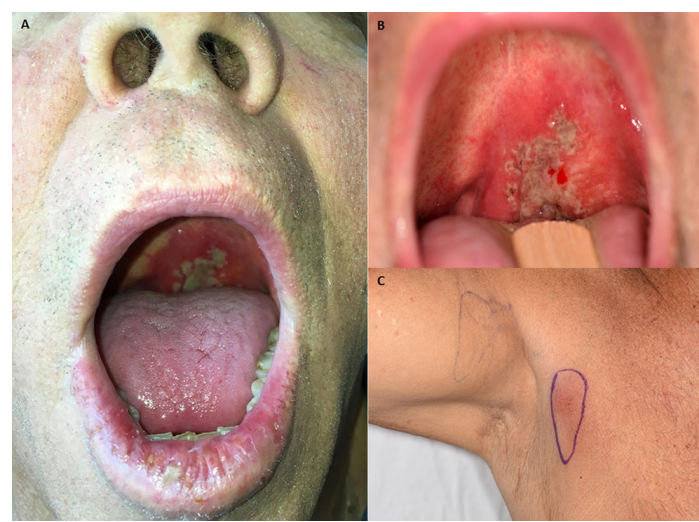

Figure 1 Tonsillar and pharyngeal lesions which appear ulcerated, inflamed and necrotic (A, B). Erythematous, slightly tender axillary lesion that appeared after the tonsillar lesion. Possibly represents Vibrio vulnificus cellulitis as it had optimal response to antibiotic treatment (C).

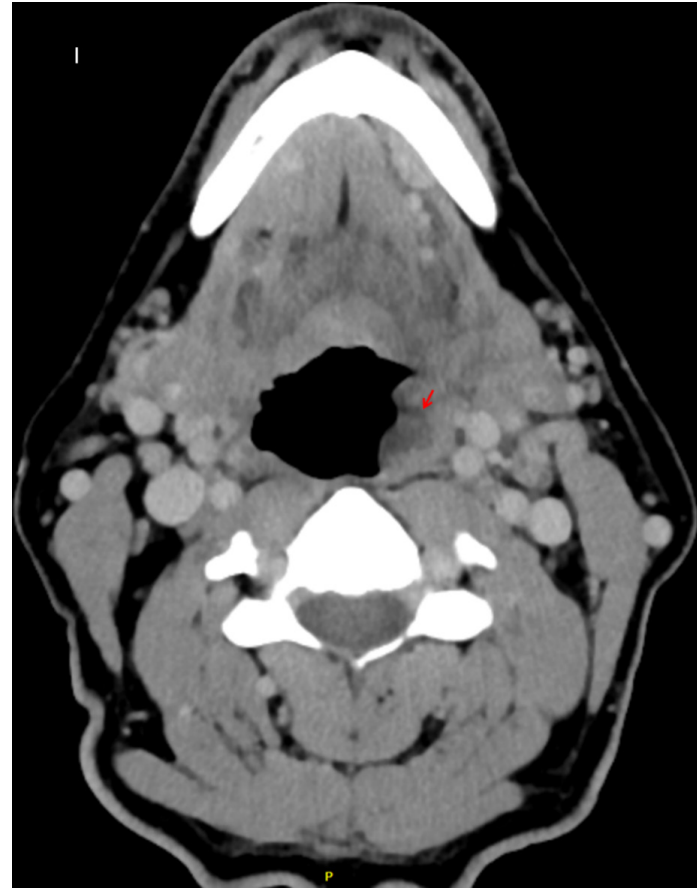

Figure 2 CT of the neck showing swelling of the left tonsil with submucosal tonsil oedema and enlarged, inflamed left palatine tonsil (arrow). Reactive neck lymphadenopathy was noticed as well.

Infection may be contracted by consuming undercooked seafood or swimming in contaminated sea water. ${ }^{2}$ Acute tonsillitis caused by V. vulnificus is rare, with no reported cases in the literature. Our patient had concomitant HSV-1 infection which may have served as a port of entry to the bloodstream. His axillary lesion (figure 1) could likely be a vibrio cellulitis from haematogenous spread in the setting of positive blood cultures and absence of trauma along with quick resolution on antibiotic therapy. V. vulnificus is usually susceptible to tetracyclines alone, but adding a cephalosporin is associated with better therapeutic response. ${ }^{3}$

Learning points

- V.vulnificus tonsillitis is rare and can lead to septicaemia in susceptible patients.

- V.vulnificus infection should be suspected in patients with cirrhosis with soft tissue infections.

- Tetracycline with or without cephalosporin is usually sufficient to treat this potentially lethal Gram-negative bacterium. 


\section{Images in...}

Contributors AAA authored the manuscript. DAS, BTK and JBC carefully reviewed the manuscript. All authors approved the manuscript for submission.

Competing interests None declared.

\section{Patient consent Obtained.}

Provenance and peer review Not commissioned; externally peer reviewed.

(c) BMJ Publishing Group Ltd (unless otherwise stated in the text of the article) 2017. All rights reserved. No commercial use is permitted unless otherwise expressly granted.

\section{REFERENCES}

1 Nazir S, Brown K, Shin AK, et al. Vibrio vulnificus infection and liver cirrhosis: a potentially lethal combination. BMJ Case Rep 2016;2016:bcr2016214772.

2 Vollberg CM, Herrera JL. Vibrio vulnificus infection: an important cause of septicemia in patients with cirrhosis. South Med J 1997;90:1040-2.

3 Yu W, Shen X, Pan H, et al. Clinical features and treatment of patients with Vibrio vulnificus infection. Int J Infect Dis 2017;59:1-6.

Copyright 2017 BMJ Publishing Group. All rights reserved. For permission to reuse any of this content visit http://group.bmj.com/group/rights-licensing/permissions.

BMJ Case Report Fellows may re-use this article for personal use and teaching without any further permission.

Become a Fellow of BMJ Case Reports today and you can:

- Submit as many cases as you like

Enjoy fast sympathetic peer review and rapid publication of accepted articles

- Access all the published articles

Re-use any of the published material for personal use and teaching without further permission

For information on Institutional Fellowships contact consortiasales@bmjgroup.com

Visit casereports.bmj.com for more articles like this and to become a Fellow 